\title{
Düzce ili fındık bahçelerinde külleme hastalığının bulunma oranı, hastalık şiddeti ve yaygınlığının belirlenmesi
}

\author{
$\underline{\text { Nedim ALTIN }}^{1}$
}

\author{
ABSTRACT \\ Determination of incidence, disease severity and prevalence of powdery \\ mildew in hazelnut orchards in Düzce province
}

\begin{abstract}
This study was carried out to determine the incidence, disease severity and prevalence of powdery mildew disease, which turned into an epidemic disease, in hazelnut orchards of Düzce in 2016. During the survey, sampling was carried out in 800 plant plot in 62 hazelnut orchards. In the survey, approximately $1 / 40.000$ of hazelnut plant plot in the districts have been examined. Samplings were carried out between June and July. To determine the disease severity, 40 leaves randomly were collected from 4 different direction of each plant plot, except for the two leaves at the bottom of the shoots on the branches and disease severity was evaluated according to 0-4 scale. As a result of this study, it was determined that the main pathogens of powdery mildew disease in hazelnut in Düzce were Erysiphe sp. (Section Microsphaera) and Phyllactinia guttata which were known to occur on hazelnut in Turkey. The prevalence, incidence and severity of the disease in the orchards of the province were $100 \%, 87.38 \%$ and $35.01 \%$, respectively.
\end{abstract}

Keywords: Erysiphe sp, hazelnut, powdery mildew, Phyllactinia guttata

\section{ÖZ}

Bu çalışma 2016 yılında Düzce ili findık bahçelerinde epidemi yapan külleme hastalığının bulunma oranının, hastalık şiddetinin ve yaygınlı̆̆ının belirlenmesi amacıyla yapılmıştır. Survey çalışmaları esnasında 62 adet findık bahçesinde 800 ocakta örnekleme yapılmıştır. Survey çalışmalarında ilçelerdeki fındık ocaklarının yaklaşık olarak 1/40.000'i incelenmiştir. Örneklemeler haziran-temmuz aylarında gerçekleştirilmiştir. Hastalık şiddetini belirlemek amacıyla her bir ocağın dört yönünden, dallar üzerindeki sürgünlerden en dipteki iki yaprak haricindeki yapraklardan tesadüfen 40 'ar yaprak alınmış ve hastalık şiddeti 0-4 skalasına göre değerlendirilmiştir. Değerlendirmeler sonucunda Düzce ilinde findıkta külleme

\footnotetext{
${ }^{1}$ Düzce Üniversitesi, Ziraat ve Doğa Bilimleri Fakültesi, Bitki Koruma Bölümü Sorumlu yazar (Corresponding author) e-mail: nedimaltin@duzce.edu.tr Alınış (Received): 28.12.2016, Kabul ediliş (Accepted): 11.05.2017
} 
hastalığına neden olan etmenin ülkemizde varlığı bilinen Erysiphe (Seksiyon: Microsphaera) sp. ve Phyllactinia guttata olduğu belirlenmiştir. İl genelinde findık bahçelerinde külleme hastalığının yaygınlık oranı, bulunma oranı ve hastalık şiddeti sırasıyla $\% 100, \% 87.38$ ve \%35.01'dir.

Anahtar kelimeler: Erysiphe sp, findık, külleme, Phyllactinia guttata

\section{GİRIŞ}

Ülkemizde kültürü yapılan findık çeşitlerimizin büyük bir kısmı Corylus maxima ile Corylus avellana'nın melezlemeleri sonucunda elde edilmiştir. Ülkemiz Dünyadaki fındık üretiminin yaklaşık \%70'ni gerçekleştirmektedir. Başta Karadeniz Bölgesi olmak üzere 39 ilde findık üretilebilmektedir. Ülkemize önemli bir döviz girdisi sağlayan findık tarımsal ürün ihracatımızda yaklaşık \%15-20 paya sahiptir (Anonim 2017). Fındık tarımı Türkiye'de yaygın ve ekonomik olarak Doğu ve Batı Karadeniz Bölgesinde yapılmaktadır. Fındık bu bölgeler için ekonomik ve sosyal açıdan stratejik öneme sahiptir (Tanrıvermiş ve ark. 2006).

Batı Karadeniz Bölgesinde yer alan Düzce ili bulunduğu coğrafik konumu, iklimi ve tarımsal sanayiye yakınlığı ile findık üretiminin yoğun yapıldığı yerlerden birisidir. İstatistik verilerine göre Türkiye'de findık üretimi 7.026.279 da'llk alanda yapılmaktadır. Türkiye'deki fındık üretimi göz önüne alındığında Düzce ilindeki 626.858 da' lık alanda yapılan üretim Türkiye genelinde önemli bir yer tutmaktadır (Anonim 2016a).

Fındık tarımında üretimi etkileyen fungal, bakteriyel ve viral hastalık etmenleri bulunmaktadır. Bu hastalık etmenlerinden bazıları Findık bakteriyel yanıklık etmeni (Xanthomonas arboricola pv. corylina Miller et al.), Fındık külleme hastalık etmeni [Phyllactinia guttata (Wallr.: Fr.) Lev.], Findık dal kanseri etmeni (Nectria galligena Bres.), Armillaria kök çürüklüğü etmeni [Armillaria mellea (Vall.) Quel.], Rosellinia kök çürüklüğü etmeni (Rosellinia necatrix Prill) ve Fındık mozaik hastalığı etmeni (Apple mosaic virus)'dır (Kara 2012).

Ülkemizde Fındıkta külleme hastalığı ilk olarak 1943 yılında Bremer tarafindan tespit edilmiştir (Anonymous 2017). Günümüze kadar findıkta külleme hastalığı ile ilgili farklı çalışmalar yapılmıştır (Ecevit ve ark. 1996, Erper et al. 2012, Yürüt et al. 1994). Findıkta külleme hastalığına neden olan etmenler Phyllactinia guttata (Wallr.: Fr.) Lev. ve Erysiphe (Seksiyon: Microsphaera) sp.'dir. P. guttata ülkemizde findıkta son y1llara kadar en bilinen ve en sık görülen fungal hastalık etmeni olup, bazı üretim alanlarında yıllara göre $\% 70$ ve hatta \%100'lere varan oranlarda hastalık oluşturduğu belirtilmektedir (Anonim 2016b). Ülkemiz findık üretim alanlarında ilk olarak 2013 yılında görülen diğer külleme etmeni ise Erysiphe sp.'dir. Bu etmenler ülkemizde tüm findık üretim alanlarında ekonomik anlamda zarar oluşturmaktadırlar (Anonim 2016b). Düzce ilinde son dönemde özellikle 2015 ve 2016 yıllarında findık yetiştiriciliğinde ekonomik anlamda zarar oluşturmaya başlamıştır. 
Phyllactinia guttata etmeninin miselleri saydam, bükülmüş kordon gibi ve üzeri siğilli görünüş̧tedir. Miselyum genelde konukçu yapraklarının alt yüzeyinde, nadiren üst yüzeyinde görülür. Konidileri tek hücreli, çomak şeklinde veya bazen romboid (baklava dilimi)' dir. Kleistotesyumlar yayvan olup 3-15 adet tutunucu kol içerir. Tutunucu kolların taban kısmında ayırt edici şekilde bir şişkinlik vardır. Kleistotesyumlarda çomak şekilli 6-30 adet askus ve her bir askusta iki adet eliptik askospor bulunur (Anonim 2016b). Genelde Erysiphe sp. etmeninin miselleri çoğunlukla dallanmış saydam, beyaz veya renksiz bölmelidir. Konidiler tek hücreli, elips veya fiçı şeklinde olup konidoforlar üzerinde zincir şeklinde oluşur. Kleistotesyumlar uçta dikotom dallanma gösteren tutunucu kol içerir (Anonim 2016b, Braun 1987).

Tarımsal üretimde kültürü yapılan bitkilerde zarar oluşturan hastalıkların durumlarının tespitine yönelik çalışmaların yapılmaması durumunda önemli kayıpların oluşması kaçınılmazdır. Bitkilerde hastalık oluşturan etmenlerin epidemi oluşturması durumunda üretim alanındaki tüm bitkiler hastalanmakta ve çoğu ölmektedir. Bitkilerde oluşan bu kayıpların önüne geçilebilmesi için hastalık etmenleri ile mücadele etmek gerekmektedir. Bunu yapabilmek için de öncelikle mücadele yapılacak etmenin o bölgedeki durumunu belirlemek amacıyla varlığının tespiti ve teşhisinin yapılması gerekmektedir (Kurt 2013). Bu çalışma 2016 yılında Düzce ili findık bahçelerinde külleme hastalığının bulunma oranının, hastalık şiddetinin ve yaygınlığının belirlenmesi amacıyla yapılmıştır.

\section{MATERYAL VE METOT}

Külleme hastalığı ile ilgili 2016 yılında yapılan survey çalışmaları meyve içlerinin nispeten geliştiği ve hastalıkla ilgili belirtilerin gözlenmesi için uygun periyot olan haziran-temmuz aylarında gerçekleştirilmiştir. Survey çalışmalarında ilçelerdeki findık ocaklarının yaklaşık olarak 1/40.000'i incelenmiştir. Düzce iline ait ilçelerin ocak ve örnekleme sayıları Çizelge 1'de verilmiştir.

Çizelge 1. Fındıkta külleme hastalığının surveyinde ilçelerin ocak ve örnekleme sayıları

\begin{tabular}{|c|c|c|c|c|c|}
\hline \multirow[b]{2}{*}{ İlçeler } & \multirow{2}{*}{$\begin{array}{c}\text { Fındık } \\
\text { Üretim } \\
\text { Alanı (da) }\end{array}$} & \multirow{2}{*}{$\begin{array}{l}\text { Toplam Ocak } \\
\text { Sayısı (Adet) }\end{array}$} & \multicolumn{3}{|c|}{ İncelenen } \\
\hline & & & $\begin{array}{c}\text { Ocak Sayısı } \\
\text { (Adet) }\end{array}$ & $\begin{array}{l}\text { Bahçe } \\
\text { (Adet) }\end{array}$ & $\begin{array}{c}\text { Alan } \\
\text { (da) }\end{array}$ \\
\hline Merkez & 129.000 & 6.540 .000 & 150 & 13 & 51 \\
\hline Akçakoca & 218.658 & 10.943 .000 & 280 & 22 & 100 \\
\hline Cumayeri & 54.000 & 3.240 .000 & 60 & 5 & 22 \\
\hline Çilimli & 35.250 & 1.764 .500 & 70 & 4 & 25 \\
\hline Gölyaka & 42.290 & 2.114 .647 & 40 & 4 & 14 \\
\hline Gümüşova & 34.760 & 1.739 .000 & 30 & 3 & 13 \\
\hline Kaynaşlı & 22.900 & 1.149 .510 & 30 & 2 & 10 \\
\hline Yığglca & 90.000 & 4.501 .000 & 140 & 9 & 58 \\
\hline Toplam & 626.858 & 31.991 .657 & 800 & 62 & 293 \\
\hline
\end{tabular}


Survey çalışmalarında, tüm yöreyi temsil edecek şekilde tesadüfi örnekleme yöntemi uygulanmıştır (Bora ve Karaca 1970). Bahçe büyüklüğü 1-5 da ise 10 ocak, 6-10 da ise 20 ocak, 11-20 da ise 30 ocak ve 20 da' dan büyük ise 40 ocak incelenmiştir (Sezer ve Dolar 2012).

Hastalık şiddetini belirlemek amacıyla her bir ocağın dört yönünden, dallar üzerindeki sürgünlerden en dipteki iki yaprak haricindeki yapraklardan tesadüfen 40'ar yaprak alınmıştır. Değerlendirme Çizelge 2'de verilen 0-4 skalasına göre yapılmıştır. Meyve enfeksiyonlarını belirlemek için her ocaktan tesadüfen 30'ar çotanak alınmıştır. Değerlendirme çotanaklarda hasta-sağlam şeklinde yapılmıştır (Anonim 2016c).

Çizelge 2. Fındıkta külleme hastalığı değerlendirme skalası (Anonim 2016c).

\begin{tabular}{|l|l|}
\hline Skala Değeri & Tanım \\
\hline $\mathbf{0}$ & Yaprakta hiç külleme belirtisi yok \\
\hline $\mathbf{1}$ & Yaprak yüzeyinin \%1-10’u küllemeli \\
\hline $\mathbf{2}$ & Yaprak yüzeyinin \%11-30'u küllemeli \\
\hline $\mathbf{3}$ & Yaprak yüzeyinin \% 31-60'` küllemeli \\
\hline $\mathbf{4}$ & Yaprak yüzeyinin \% 60'dan fazlası küllemeli \\
\hline
\end{tabular}

Tesadüfi olarak incelenen yapraklardan elde edilen skala değerleri üzerinden Tawnsend-Heuberger formülüne göre hastalık şiddeti (\%) belirlenmiştir. Yapılan survey çalışmaları sonucunda her bahçede hastalık belirtisi gösteren yapraklar, incelenen toplam yaprak sayısına oranlanarak hastalığın bahçede bulunma oranı tespit edilmiştir. İncelenen bahçelerde hastalık şiddeti ve bulunma oranı belirlendikten sonra, tartılı ortalama ile ilçelere ve ile ait hastalık şiddeti ve bulunma oranı belirlenmiştir (Bora ve Karaca 1970). Surveyler esnasında hastalığın görüldüğü fındık bahçeleri bulaşık kabul edilip, incelenen fındık bahçesi sayısına oranlanarak da hastalığın yaygınlık oranı hesaplanmıştır (Karman 1971).

Düzce ilinde findık bahçelerinde görülen külleme hastalığının etmenini belirlemek amacıyla hastalık belirtisi gösteren yapraklardan örnekler alınmıştır. Örnekler kese kâğıdına konularak buz kutusu içerisinde laboratuvara getirilmiştir. Laboratuvara getirilen hastalıklı bitki örneklerinden yapılan preparatlarla etmenin konidileri, kleistotesyumları, askus ve askosporlarının şekilleri mikroskop altında belirlenmiş ve ölçümleri yapılarak fungusun teşhisi yapılmıştır. Teşhis çalışmalarında ağırlıklı olarak Boesewinkel (1980), Braun (1995), Braun et al. (2002)'den yararlanılmıştır.

\section{SONUCLAR VE TARTIŞMA}

Düzce ilinde 2016 yılında yapılan survey çalışmalarında toplam 62 adet findık bahçesi incelenmiştir. İl genelinde yaklaşık olarak 31.991.657 adet findık ocağ 1 bulunmaktadır. Survey yöntemi gereği bu ocakların yaklaşık olarak 1/40.000'i incelenmiştir. Buna göre 62 adet findık bahçesinde 800 ocakta örnekleme yapılmıştır. Örnekleme yapılan findık bahçelerinin toplam büyüklüğü 293 da'dır. 
Fındık bahçelerinde külleme hastalığının yaygınlığını ve şiddetini belirlemek amacıyla haziran-temmuz aylarında yapılan survey çalışmalarından önce külleme hastalığının gelişimini takip etmek amacıyla fındık yaprakları normal büyüklügünü aldıktan sonra arazide gözlemlere başlanmıştır. Yapılan gözlemler sonucunda findık bahçelerinde ilk hastalık belirtileri mayıs ayının başında tespit edilmiştir. Genelde yaprağın her iki yüzünde de hastalık belirtileri görülmüsstür. Yaprağın alt yüzeyinde fungusun misellerinin ve sporlarının oluşmasının ardından yaprağın üst yüzeyinde sarımsı lekeler görülmüştür. Hastalık ilerledikçe, yaprağın üzerinde beyaz fungal bir örtü oluşmuştur (Şekil 1). Zamanla bu lekelerin beyaz renkten grimsi renge döndüğü gözlenmiş̧ir. İlerleyen dönemde bu lekelerin üzerinde bol miktarda etmenin kahverengimsi ve siyahımsı renklerde kleitotesyumları oluşmuştur. Hastalığın ilerlemesiyle bulaşık yaprakların kıvrıldığı, kuruduğu ve vaktinden önce döküldüğü görülmüştür. Benzer belirtiler genç sürgünlerde ve çotanak zuruflarında da görülmüştür (Şekil 1). Gelişme sezonunun sonuna doğru olan dönemde findık yapraklarının genellikle alt yüzeyinde $P$. guttata'nın beyaz renkli kolonileri görülmüştür. İlerleyen dönemde etmenin misel ve konidilerinden oluşan tozlu beyaz lekelerin yaprağın büyük bir bölümünü kapladığı görülmüştür. Bu lekelerin üzerinde etmenin kahverengi siyahımsı renkte kleistotesyumları oluşmuştur. Yapılan birçok çalışmada külleme etmenlerinin findıkta ve diğer kültür bitkilerinde oluşturdukları belirtiler belirlenmiştir (Anonymous 2016a, Hartney et al. 2005, Severoğlu and Özyiğit 2012). Bu çalışmalarda saptanan belirtiler ile yapmış olduğumuz gözlemler benzerlik göstermektedir. Yapılan gözlemlerde $P$. guttata etmeninin oluşturmuş olduğu kleistotesyumların Erysiphe sp.'nin oluşturmuş olduğu kleistotesyumlardan belirgin bir şekilde daha büyük olduğu görülmüştür.

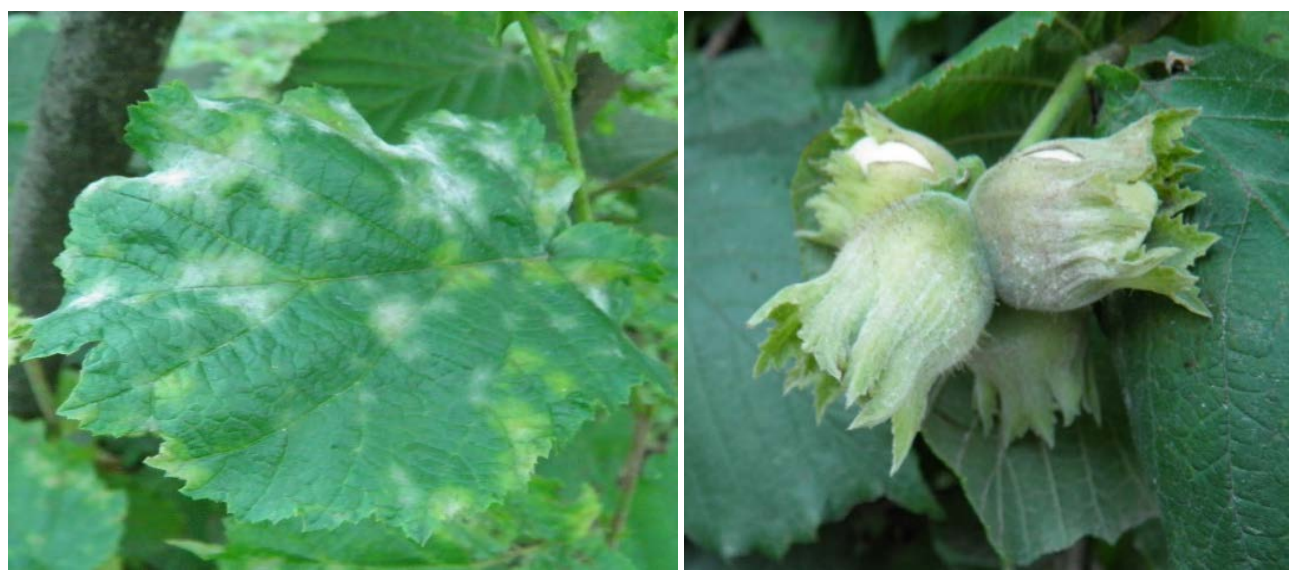

Şekil 1. Yaprakta ve çotanakta külleme hastalığının belirtileri.

Survey çalışmaları sırasında hastalık etmenini belirlemek amacıyla findık bahçelerinden alınan hastalıklı yapraklar laboratuvara getirilmiş ve mikroskop altında incelenmiş̧tir. Yapılan incelemelerde Erysiphe sp. olarak belirlenen etmenin konidilerinin elips veya fiçı şeklinde, ölçümler sonucunda uzunluklarının yaklaşı olarak 16-23 $\mu \mathrm{m}$, çaplarının ise 12-15 $\mu \mathrm{m}$ arasında olduğu belirlenmiştir. 
Kleistotesyum uzantılarının uçta dikotom dallanma gösterdiği görülmüştür. Her kleistotesyumda yaklaşık olarak 8-11 adet uzantı bulunmaktadır. Kleistotesyumların çapları yaklaşık olarak 53-57 $\mu \mathrm{m}$ olarak ölçülmüştür. Bir kleistotesyum içerisinde 46-52 x 36-38 $\mu \mathrm{m}$ boyutlarında 3-5 adet askus vardır. Her askusun içerisinde de 1820 x 12-14 $\mu$ m boyutlarında 6-8 adet askospor bulunmaktadır (Şekil 2). Erysiphe sp. ile yapılmış birçok çalışma bulunmaktadır (Braun et al. 2002, Kandilci 2006, Sharifi et al. 2014). Bu çalışmalarda etmenin morfolojisi ile ilgili elde edilen veriler incelendiğinde çalışmamızda elde etmiş olduğumuz veriler ile benzerlik göstermektedir. $P$. guttata olarak belirlenen etmenin kleistotesyumlarında 4-14 adet tutunucu kol olduğu belirlenmiştir. $\mathrm{Bu}$ tutunucu kolların taban kısmında bariz şekilde görünen bir şişkinlik bulunduğu görülmüştür. Kleistotesyumların çapları yaklaşık olarak 195-213 $\mu \mathrm{m}$ olarak ölçülmüştür. Bir kleistotesyum içerisinde 31-35 x 76-86 $\mu$ m boyutlarında 6-19 adet askus bulunmaktadır (Şekil 3). Her bir askusta iki adet eliptik askospor mevcuttur. Askosporlar boyutları 31-41 x 19-23 $\mu \mathrm{m}$ ebatlarında ölçülmüştür. $P$. guttata'nın tespitine yönelik olarak yapılan çalışmada elde edilen veriler çalışmamızda elde edilen veriler ile paralellik göstermektedir (Anonymous 2016b, Braun et al. 2002, Hartney et al. 2005).

Mikroskop altında yapılan incelemeler ve ölçümler sonucunda Düzce ilinde Fındıkta külleme hastalığına neden olan etmenlerin Erysiphe sp. ve $P$. guttata olduğu belirlenmiştir. Ancak bölgede vejetasyon dönemin başından survey çalışmalarının yapıldığı haziran-temmuz ayına kadar olan dönemde $P$. guttata etmeninin varlığına rastlanılmamıştır. Gelişme sezonunun sonuna doğru olan dönemde findık yapraklarının genellikle alt yüzeyinde $P$. guttata'nın beyaz renkli kolonileri görülmüştür. Bu durum Zirai Mücadele Teknik Talimatında yer alan bilgilerle de benzerlik göstermektedir (Anonim 2016b). Survey esnasında değerlendirmelerin yapıldığı dönemde Erysiphe sp. ile bulaşık olan findık yapraklarında bol miktarda kleistotesyumların oluştuğu görülmüştür.
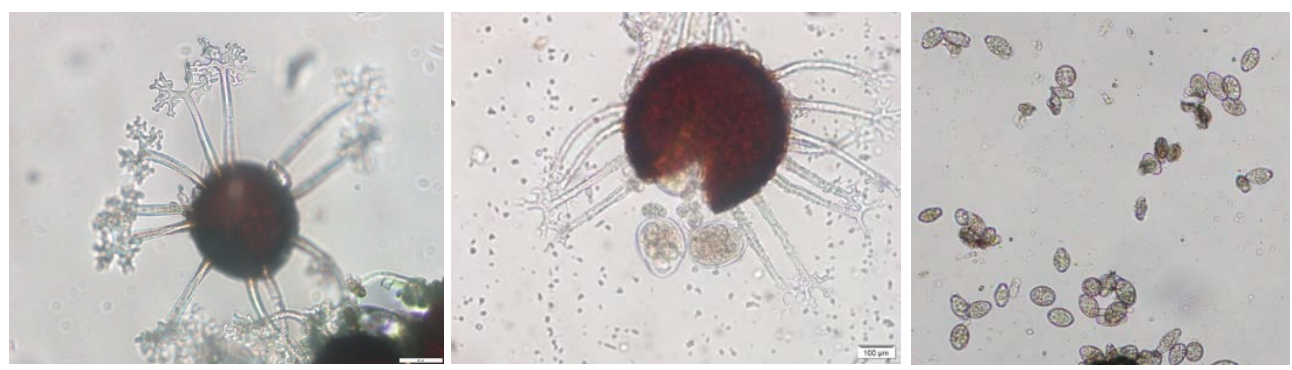

Şekil 2. Erysiphe sp.’nin kleistotesyum, askus ve konidileri 

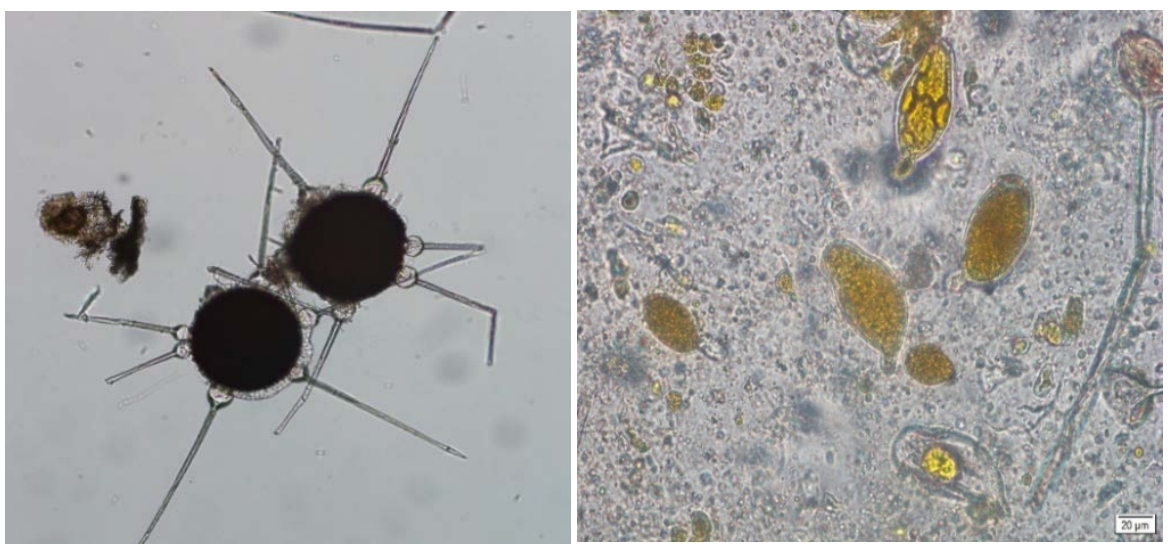

Şekil 3. Phyllactinia guttata'nın kleistotesyumları ve askusları

Survey yapılan findık ocaklarında yapraklar 0-4 skalasına göre değerlendirilmiştir. Skala değerine göre yapılan değerlendirmeler sonucunda elde edilen veriler ile külleme hastalığının il ve ilçe genelinde hastalık şiddeti hesaplanmıştır. Hastalığın incelenen yapraklarda bulunup bulunmamasina göre de bulunma oranları belirlenmiştir. Hesaplamalar sonucunda elde edilen hastalık şiddeti değerleri ve bulunma oranları Çizelge 3'de verilmiştir. Çizelge 3 incelendiğinde Düzce ili genelinde hastalığın bulunma oranının ortalama \%87.38 olduğu görülmektedir. İncelenen findık bahçelerinde genelde hastalığın bulunma oranlarının yüksek olduğu görülmüştür. Surveyler sonucunda ilçelerde hastalığın bulunma oranlarının birbirine yakın olduğu belirlenmiştir. Çizelge 3'de ilçeler bazında en düşük bulunma oranının \%80 ile Gümüşova ilçesinde en yüksek bulunma oranın ise \%93.33 ile Kaynaşlı ilçesinde olduğu görülmektedir.

Çizelge 3. Düzce ilinde Fındıkta külleme hastalığının bulunma oranları ve hastalık şiddeti değerleri.

\begin{tabular}{|l|c|c|c|}
\hline \multirow{2}{*}{ İlçeler } & \multicolumn{2}{|c|}{ Yapraklarda } & $\begin{array}{c}\text { Çotanaklarda } \\
\text { Hastalık Oranı \% }\end{array}$ \\
\cline { 2 - 3 } & $\begin{array}{c}\text { Hastalığın Bulunma } \\
\text { Oranı \% }\end{array}$ & Hastalık Şiddeti \% & 8,38 \\
\hline Merkez & 86,00 & 30,33 & 8,59 \\
\hline Akçakoca & 90,71 & 39,28 & 7,78 \\
\hline Cumayeri & 83,33 & 39,47 & 8,89 \\
\hline Çilimli & 91,43 & 40,70 & 4,44 \\
\hline Gölyaka & 87,50 & 36,61 & 8,15 \\
\hline Gümüşova & 80,00 & 44,68 & 3,89 \\
\hline Kaynaşlı & 93,33 & 36,17 & 5,31 \\
\hline Yığılca & 83,14 & 24,84 & 6,93 \\
\hline Ortalama & 87,38 & 35,01 & \\
\hline
\end{tabular}

Bolu, Zonguldak ve Bartın illerinde 1988-1990 yıllarında findık hastalıklarının tespitine yönelik survey çalışması yapılmıştır. Yapılan bu çalışmada Phyllactinia suffulta etmenin neden olduğu külleme hastalığının yıllara göre hastalık oranı 
Bartın'da \%20, \%81.7, \%4.6; Ereğli'de \%67, \%53.3, \%34.4; Akçakoca’da \%71.6, $\% 56, \% 37.3$ olarak belirlenmiştir. Düzce'de ise üç y1lda da hastalık görülmemiştir (Yürüt et al. 1994) Akçakoca'da belirlenen yüksek hastalık oranları çalışmamızda elde ettiğimiz verileri desteklemektedir.

Tablo 1'deki hastalık şiddeti verileri incelendiğinde ise il genelinde ortalama \%35.01 oranında hastalık şiddeti olduğu görülmektedir. İlçelerde en düşük hastalık şiddeti \%24.84 ile Yığılca ilçesinde en yüksek hastalık şiddetinin \%44.68 ile Gümüşova ilçesinde olduğu görülmektedir. Surveyler esnasında inceleme yapılan 62 adet findık bahçesinin tamamında hastalık belirtileri bulunmuştur. Buna göre hem ilçelerde hem de il genelinde hastalığın yaygınlık oranı \%100 olarak belirlenmiştir.

Çotanaklarda ise il genelinde hastalık oranının ortalama \%6.93 olduğu belirlenmiştir. Çotanaklarda en düşük hastalık oranı \%3.89 ile Kaynaşlı ilçesinde en yüksek hastalık oranı ise \%8.89 ile Çilimli ilçesinde görülmüştür.

Sonuç olarak 2016 yılında külleme etmenleri Düzce ili findık üretim alanlarında önemli zararlara neden olmuş ve bölgedeki inokulum potansiyeli yükselmiştir. Bu durum önümüzdeki yıllarda bu hastalığın mücadelesine yönelik çalışmaların yapılmasını zorunlu kılmaktadır. Özellikle hastalığa karşı tolerant çeşitlerin geliştirilmesi konusunda çalışmaların yapılmasının yararlı olacağı düşünülmektedir. 


\section{KAYNAKLAR}

Anonim 2016a. http://www.tuik.gov.tr (Erişim Tarihi: 11.11.2016)

Anonim 2016b. http://www.tarim.gov.tr/TAGEM/Belgeler/yayin/Bitki Hastalıkları/Zirai Mücadele Teknik Talimatları. pdf (Erişim Tarihi: 11.11.2016)

Anonim 2016c. Meyve ve Bağ Hastalıkları Standart İlaç Deneme Metodu http://www.tarim.gov.tr/TAGEM/Belgeler/yayin/Meyve-Bağ Hastalıkları Standart İlaç Deneme Metotları.pdf (Erişim Tarihi: 25.12.2016)

Anonim 2017. 2015 Y1lı Fındık Raporu http://koop.gtb.gov.tr/data/Raporu.pdf (Erişim tarihi: 31.01.2017)

Anonymous 2016a. Hazelnut (Corylus avellana)-Powdery Mildew https://pnwhandbooks. org/ node/2851 (ErişimTarihi: 01.11.2016)

Anonymous 2016b. Phyllactinia guttata https://en.wikipedia.org/w/index.php title=Phyllactinia guttata\&old id=677751603 (Erișim tarihi:01.11.2016)

Anonymous 2017. The Erysiphales Collection at the Botanische Staatssammlung München http://www.botanischestaatssammlung.de/DatabaseClients/BSMeryscoll/Diversity Collection_BSMeryscoll_Find.cfm

Bora T. ve Karaca İ. 1970. Kültür Bitkilerinde Hastalığın ve Zararın Ölçülmesi. Ege Üniversitesi, Ziraat Fakültesi, Yardımcı Ders Kitabı. Yayın no: 167. s: 43. Bornova.

Boesewinkel H. J. 1980. The Morphology of the Imperfect States of Powdery Mildews (Erysiphaceae). The Botanical Review, 46, 167-224.

Braun U. 1987. A Monograph of the Erysiphales (powdery mildews). Beihefte zur Nova Hedwigia. 89:1-700.

Braun U. 1995. The Powdery Mildews (Erysiphales) of Europe. Gustav Fischer. 219 pp.

Braun U., Cook R. T. A., Inman A. I. and Shin H. D. 2002. The Powdery Mildews: A Comprehensive Treatise. In: Belanger, R. R., Bushnell, W. R., Dik, A. I. Carver, T.l.W. (eds). The Taxonomy of the Powdery Mildew Fungi, pp 13-55. St. Paul, American Phytopathological Society (APS Press). USA.

Ecevit O., Özman S. K., Hatat G., Okay M. N., Kaya A. ve Mennan S. 1996. Karadeniz Bölgesinde Önemli Fındık Çeşitlerinin Zararlı ve Hastalıklara Karşı Duyarlılıklarının Belirlenmesi. Fındık ve Diğer Sert Kabuklu Meyveler Sempozyumu, Ondokuz Mayıs Üniversitesi, 10-11 Ocak 1996, s. 77-93, Samsun.

Erper İ., Türkkan M., Karaca G. H. and Kılıç G. 2012. New Hosts for Phyllactinia guttata in the Black Sea Region of Turkey, Scandinavian Journal of Forest Research, 27:5, 432437.

Hartney S., Glawe D. A., Dugan F. and Ammirati J. 2005. First Report of Powdery Mildew on Corylus avellana Caused by Phyllactinia guttata in Washington State. Online. Plant Health Progress doi:10.1094/PHP-2005-1121-01-BR. 
Kandilci P. 2006. Adana Yöresinde Bitkisel Ürünlerde ve Yabancı Otlar Üzerinde Görülen Külleme Hastalıkları ve Etmenleri. Yüksek lisans tezi, Çukurova Üniversitesi Fen Bilimleri Enstitüsü, Adana, 52s.

Kara Ç. 2012. Fındık Bakteriyel Yanıklık Etmeni Xanthomonas arboricola pv. corylina'nın Samsun İlinde Yaygınlığının Belirlenmesi. Yüksek lisans tezi, Ondokuz Mayıs Üniversitesi Fen Bilimleri Enstitüsü, Samsun, 44s.

Karman M. 1971. Bitki Koruma Araştırmalarında Genel Bilgiler Kitabı. T.C. Tarım Bakanlığı Zirai Mücadele ve Zirai Karantina Genel Müdürlüğü Yayınları. Bornova/İzmir. Ağustos 1971. s:279.

Kurt Ş. 2013. Bitki Fungal Hastalıkları. Akademisyen Kitap Evi. ISBN: 978-605-464-901-3. Ankara. s: 214.

Severoğlu Z. and Özyiğit İ. İ. 2012. Powdery Mildew Disease In Some Natural And Exotic Plants of Istanbul, Turkey. Pak. J. Bot., 44: 387-393, Special Issue March 2012.

Sezer A. ve Dolar F. S. 2012. Ordu, Giresun ve Trabzon İlleri Fındık Üretim Alanlarında Çotanaklarda Hastalık Oluşturan Botrytis cinerea Pers. ex Fr.'nın Yaygınlığı ve Bazı Çeşitlerin Etmene Karşı Reaksiyonlarının Belirlenmesi, Bitki Koruma Bülteni, 52 (1): 93-110).

Sharifi K., Davari M., Khodaparast S. A. and Kheirabadi M. B. 2014. A Study on the Identification of Powdery Mildew Fungi (Erysiphaceae) in Ardabil Landscape, Iran. J. Crop. Prot., 3:663-671.

Tanrıvermiş H., Gönenç S. ve Terzioğlu S. B. 2006. Türkiye'de Fındık Üretiminin SosyoEkonomik Yapısı, Tamamlayıcı Gelir Kaynaklarını Geliştirilebilme Olanakları ve Etkilerinin Değerlendirilmesi. 3. Milli Fındık Şurası, Giresun, s: 125-144.

Yürüt H.A., Erkal Ü. and Gürer M. 1994. Hazelnut Diseases in Bolu, Düzce and Bartın. 9th Congress of the Mediterranean Phytopathological Union, Kuşadası, Aydın, Türkiye: Turkish Phytopathological Society Publications No: 7, pp. 417-419. 